Vol. 4, No. 03; 2021

ISSN: 2581-4664

\title{
USE OF THE MODIFIED DEMING TECHNOLOGY (PDSA) TO IMPROVE THE QUALITY OF HEALTH SERVICES IN AL-KADHIMIN (PEACE BE UPON HIM) MEDICAL CITY
}

\author{
Prof.A. Dr. Islam Talib Mohammed Saleh Al-Jabi \\ Administrative Technical College / Baghdad \\ Researcher Suhaila Musa Issa \\ Administrative Technical College / Baghdad \\ http://doi.org/10.35409/IJBMER.2021.3276
}

\begin{abstract}
The aim of this research is to explore the role of applying the modified Deming Technology (PDSA) in improving the quality of health services in Imam Al-Kadhimin Medical City, where the actual reality of the medical city and its strengths and weaknesses were reviewed. Identified with the checklist and work to improve it. The study is the first of its kind in the Iraqi health environment in terms of using Deming technology (PDSA) to improve service, and the results showed that Deming technology can improve the quality of health services by providing a set of solutions and treatments that will enhance the actual reality of the medical city. The research sample.
\end{abstract}

Keyword: Health Services, Improving Health Services, Modified Deming Methodology (PDSA).

\section{INTRODUCTION}

Upgrading of the health level of health organizations is based on the necessity of providing health service and improving its quality and efficiency, by constantly learning about the latest developments and developments in the health field such as treatments and new technologies that serve the patient and meet their expectations and desires and the importance they attach to the elements of the service. The organization to maintain a competitive advantage as all hospitals have similar services, but with different levels of quality in which all hospitals aim to compete with the quality of their services and prefer to choose the hospital and thus attract new (patients) customers. The modified Deming wheel (PDSA) is one of the modern ways to improve the weaknesses and enhance the strengths of Al-Imameen Al-Kazimin (Peace be upon him) Medical City.

\section{RESEARCH METHODOLOGY AND SOME PREVIOUS STUDIES}

First: Research methodology: In this chapter, the scientific path of research is defined, by identifying the research problem, its importance and the most important goals that it seeks to achieve, and then clarifying its hypothesis model and its own hypothesis, and then the most important tools used in data analysis, as follows : 
Vol. 4, No. 03; 2021

1:Research problem: the health service is a basic issue whose importance prevails in all aspects of society because of its medical, social, ethical and financial implications. Hence, health services are not similar to other services in terms of importance, type and impact as they are directly related to human life, as the medical city should pay attention Continuous introduction of improvements with the latest developments in the health system, so the need for modern practical approaches led by workers to improve the health service for patients and the use of developed quality improvement (QI) methods, including the Modified DemingTechnique (PDSA) through which a change in health service practice is introduced, replicated and included. By the workers responsible for providing the service, and based on the foregoing, the research problem can be formulated with questions that can be answered and the appropriate treatments and solutions can be found. These questions are as follows :

The first question: What is the level of quality of health services in the medical city, the study sample?

The second question: To what extent is it possible to use Deming's modified technology (PDSA) to address weaknesses in the medical city, the study sample?

2: The importance of the research: The importance of the research stems from obtaining information that helps the medical city administration the research sample to keep pace with the development and progress in the field of providing health services by contributing to improving the health services provided that reflect the health reality .

3: Research objectives: This research seeks to achieve a set of objectives, which are represented in the following

A. Identify the level of quality of health service in the medical city, the research sample .

B. .Improving weaknesses and strengthening strengths by applying a modified Deming Cycle (PDSA)

C. Contribute to presenting a set of conclusions and recommendations that would enhance the actual reality of the medical city of the research sample .

4. The research model and its hypotheses

Based on the research problem and its objectives, the research model was designed as shown in Figure (1). 
Vol. 4, No. 03; 2021

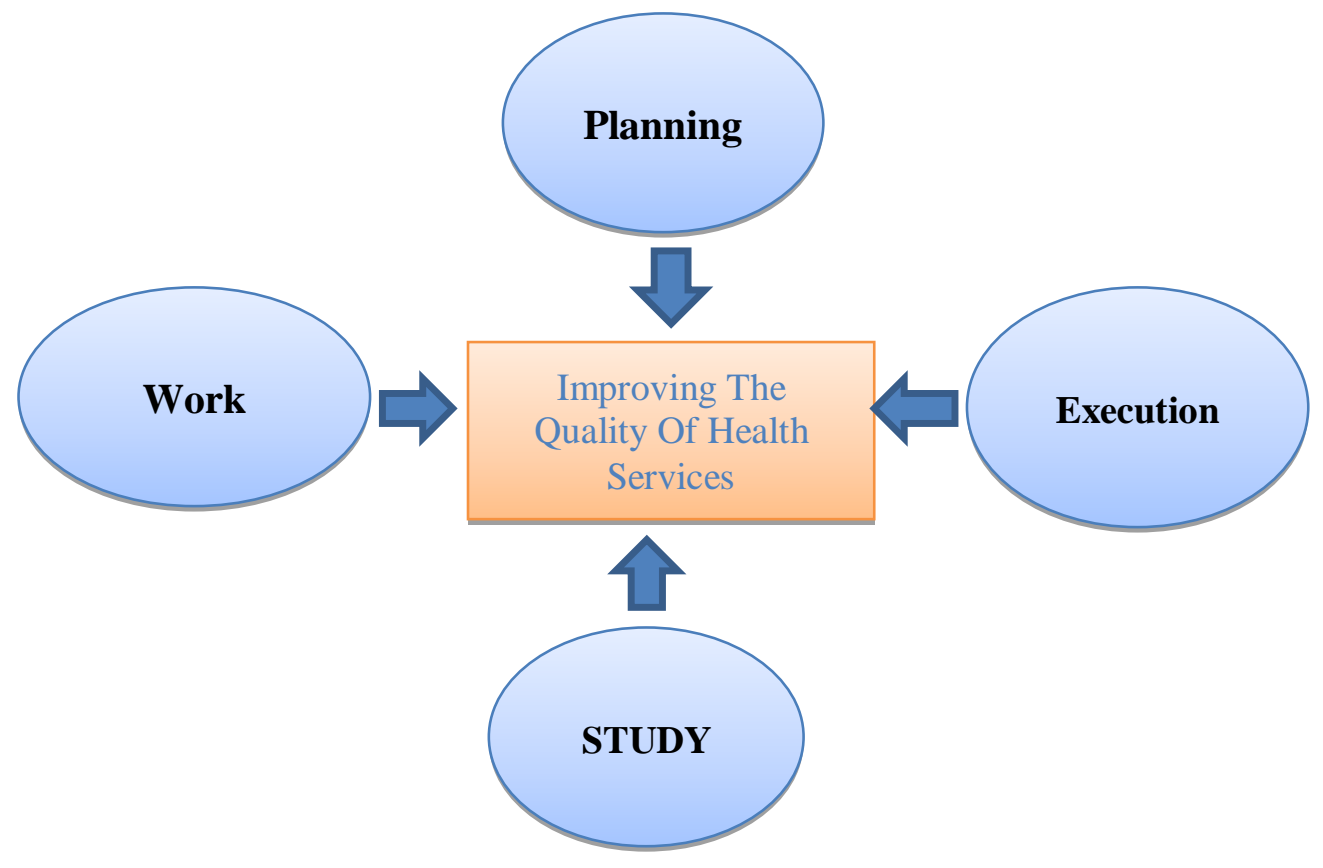

Figure (1) Research form

Source: Prepared by the researcher

This research starts from a main idea trying to test his hypothesis :

Hypothesis: "The possibility of using the modified Deming technique (PDSA) to enhance the strengths and address weaknesses in the quality of health services in the Medical City, the study sample."

\section{5- Search tools :}

A checklist was used for five dimensions (objective quality, process quality, infrastructure quality, reactive quality, general feeling quality) and the five Likert scale was relied on with relative weights $(1,2,3,4,5)$. ), and thenquantitatively analyzed the data and interpreted the results, and the strengths and weaknesses were reached .

Second: Previous studies In this part of the research, some previous ideas related to the research variable are discussed, and among the most important of these scientific efforts are the following :

1:- Study:(McNicholas et at, 2019): "Developing Quality Improvements Supporting Strategies to Improve Accuracy of the Planning Implementation Study-Acting Cycle: A mixed multimethod study". 


\section{International Journal of Business Management and Economic Review}

Vol. 4, No. 03; 2021

ISSN: 2581-4664

This study attempted to evaluate the accuracy of using the PDSA method in the practical method, and the data collected from (39)

Improvement projects between 2009 and 2012 were used, from the research evidence the actual practice of the frontline improvement team and provides an opportunity to retrospectively investigate Cycle Use (PDSA). The most prominent results of the study are thatthe use of (PDSA) technology caused statistically significant improvements in the accuracy of the improvements .

2:- Study:(Afroze et at, 2020):" Reducing neonatal hypothermia by PDSA): Initiative quality improvement in neonatal practice".

This study attempted to achieve a reduction in hypothermia as the goal is to reduce from $39 \%$ to $0 \%$ among all live newborns in the first hour of life. The quality improvement approach of Deming Technique (PDSA) in (PhulbariUpazilla) was used. One of the remote areas in Bangladesh, where Upazilla Health complex serves about $(140,392)$ people and the sample size was (41) births. There were (16) newborns with hypothermia, and hypothermia of newborns was reached in all live births who were born In the labor room, moreover, this work also indirectly improved the warm chain practice which should be followed in every neonatal careservice center.

3:- Study: (Jadoonet at, 2021):" Improving blood sugar control in patients with COVID-19: Quality Improvement Project" .

This study attempted to conduct a quality improvement project to evaluate the current practice of managing blood sugar in patients with (COVID19) in hospitals and to improve blood sugar control in these patients. The research was conducted in British hospitals, and (20133) British patients were selected. The first results of the study showed (PDSA) that although in most cases there were timely referrals to (DSN) in many cases, the most prominent results of the study were: Cases, however, monitoring and management of glycemic excursions were sub-optimal in all cases.

\section{THE THEORETICAL FRAMEWORK}

First: The origin and concept of the modified Deming technique (PDSA) PDSA arose from the efforts of Shewhart and Deming in the mid-20th century. The aim of the early use of technology was to understand "production as a system." Shewhart first presented the model in his book "The Statistical Approach to Quality Control." It consists of three processes of specifications, production and inspection in the form of a straight line. Circular, (Papcun, 2019" 57) In the 1990s, technologyin how it appears today. In particular, Deming identified the four stages, namely, planning, implementation, study, and correction, and defined the indicative summary for each of these steps, which was originally built on steps Shewhart) and Deming developed it into the PDSA (Saier, 2017:9).

As the PDSA technology is defined according to the opinions of some researchers and according 
International Journal of Business Management and Economic Review

Vol. 4, No. 03; 2021

ISSN: 2581-4664

to chronology as in Table 1

Table (1) shows the definitions of some writers and researchers in chronological order

\begin{tabular}{|l|l|}
\hline Researcher and year & Definition \\
\hline Donnelly \&Kirk,2015:279 & $\begin{array}{l}\text { A process often used to help teams improve } \\
\text { the quality of health services in a safer, more } \\
\text { effective, efficient, patient-centered and timely } \\
\text { manner. }\end{array}$ \\
\hline Coury et at,2017:2 & $\begin{array}{l}\text { A technique that helps introduce a new } \\
\text { program into the environmental community } \\
\text { that may identify a need for workflow, } \\
\text { improve efficiency, or train on best practices }\end{array}$ \\
\hline Ramadin,2018:36-A & $\begin{array}{l}\text { "A systematic series of steps to gain valuable } \\
\text { knowledge and knowledge for the continuous } \\
\text { improvement of a product or process" }\end{array}$ \\
\hline
\end{tabular}

Source: Prepared by the researcher based on the above-mentioned sources

Second. Basic Principles of Use (PDSA)

Five main principles of the method have been identified. They will be explained below and will form framework areas for assessing their use as follows (McNicholas C, et al, 2016:75) and (Knudsen et al, 2019:3)

1- Using Iterative Cycles: The central characteristic of iterative development is achieved by examining sequential iterative cycles and adapting change (Langley et al. 2009:90) and it provides the main pathway for learning and iteration of change. The approach also reflects the learning cycles used in education and organizational development depending on Knowledge gained from PDSA technology .

2- Testing based on predicting change: Informing the change testing process requires understanding and using existing knowledge to define the goal and change the concept that aims to achieve that goal. (Langley et al. 2009: 85) It can be developed from an existing external research base but also enables internal knowledge through an understanding of the national or local health service system and performance and / or the involvement and empowerment of people involved in improvement efforts (Taylor et at, 2014: 291).

3- Initial testing on a small scale: to support replication, small samples and short experimental sessions are used to learn quickly and cumulatively. Small-scale initial testing ensures that the change is modified or removed if it does not have the intended effect or the change leads to a negative response (316:Berwick 2005). 


\section{International Journal of Business Management and Economic Review}

Vol. 4, No. 03; 2021

ISSN: 2581-4664

4- Regular data usage over time: Tracking data over time is also essential to support redundancy. The measurement should be proportional to the certainty of success which in turn will guide the measure of change testing. Measurement over time allows identifying temporal relationships with tested changes and building evidence of improvement (Taylor, 2014:291).

5- Documentation: Documenting all four phases of PDSA technology, including reflections on quantitative and qualitative information, is critical. This not only clarifies whether improvement has been achieved but it ensures that learning is cumulative, informs future cycles, avoids repetition, and provides scientific accuracy of the method (McNicholas, 2016: 78).

Third: the benefits of applying PDSA technology

The use of PDSA technology results in a number of benefits, including (Leis\&Shojania, 2016:574)

1- Effective use of data, ie collecting enough information and data to reach the best improved procedures that lead to improvement .

2- .High "return on failure" ratio .

3- .Determine the necessary improvements in performance .

4- Forecasting the errors expected to occur during implementation .

5- .Increases confidence that the change under consideration will lead to improvement .

Chapter three: the applied side

First: The modified Deming technique (PDSA) is applied to the strengths and weaknesses that were identified according to the checklist for each of the five dimensions represented by (objective quality, process quality, infrastructure quality, interactive quality, quality of general feeling) to measure the quality of the health service of the medical city The research sample, and the following is an application for it:-According to its stages and for each of the dimensions of the checklist, namely:

1- After objective quality Weaknesses will be improved and the strengths revealed as a result of the checklist will be enhanced according to the following Deming technique stages:

Phase 1: Planning: The planning activity is the first step in the PDSA technique. In this phase, a plan is developed to improve weaknesses and strengthen strengths, and the prediction of change success is expressed, provides clarity on the intended effects of the change, and clarifies Improvement plan as in Table (2) improvement plan for the dimension of objectivity quality. 
International Journal of Business Management and Economic Review

Vol. 4, No. 03; 2021

ISSN: 2581-4664

Table (2) Improvement plan for the objective quality dimension

\begin{tabular}{|c|c|c|c|c|c|}
\hline No. & Weak points & $\begin{array}{l}\text { optimization } \\
\text { process }\end{array}$ & Working procedures & $\begin{array}{l}\text { Entity } \\
\text { responsible for } \\
\text { implementation }\end{array}$ & $\begin{array}{l}\text { Completion } \\
\text { time }\end{array}$ \\
\hline \multirow[t]{3}{*}{1} & \multirow[t]{3}{*}{$\begin{array}{l}\text { Poor accuracy } \\
\text { in providing } \\
\text { error-free } \\
\text { diagnostic and } \\
\text { treatment } \\
\text { services }\end{array}$} & \multirow[t]{3}{*}{$\begin{array}{l}\text { Providing } \\
\text { error-free } \\
\text { diagnostic } \\
\text { services }\end{array}$} & $\begin{array}{l}\text { A.- Keeping abreast of } \\
\text { the latest technical and } \\
\text { professional } \\
\text { developments to } \\
\text { develop capabilities by } \\
\text { providing services }\end{array}$ & \multirow[t]{3}{*}{$\begin{array}{l}\text { The senior } \\
\text { management } \\
\text { unit of } \\
\text { continuing } \\
\text { medical } \\
\text { education }\end{array}$} & \multirow[t]{4}{*}{$\begin{array}{l}2 \text { to } \\
\text { months }\end{array}$} \\
\hline & & & $\begin{array}{l}\text { B.- } \\
\text { improvements to the } \\
\text { development plan by } \\
\text { conducting training } \\
\text { courses with the latest } \\
\text { developments to apply } \\
\text { them in their daily } \\
\text { work in improving the } \\
\text { service provided }\end{array}$ & & \\
\hline & & & $\begin{array}{l}\text { C.- Providing modern } \\
\text { and advanced medical } \\
\text { equipment }\end{array}$ & & \\
\hline \multirow[t]{2}{*}{2} & $\begin{array}{l}\text { Not all medical } \\
\text { specialties are } \\
\text { available }\end{array}$ & $\begin{array}{l}\text { Providing } \\
\text { medical } \\
\text { specialties }\end{array}$ & $\begin{array}{l}\text { Providing medical staff } \\
\text { from all specialties } \\
\text { through a new } \\
\text { appointment, transfer } \\
\text { or placement from } \\
\text { outside the medical } \\
\text { city }\end{array}$ & $\begin{array}{l}\text { Higher } \\
\text { Management }\end{array}$ & \\
\hline & $\begin{array}{l}\text { strength point } \\
\text { The medical } \\
\text { staff is efficient } \\
\text { in providing } \\
\text { health services } \\
\text { to patients }\end{array}$ & $\begin{array}{l}\text { Increasing } \\
\text { the efficiency } \\
\text { of medical } \\
\text { staff in } \\
\text { providing } \\
\text { services by } \\
\text { reviewing the } \\
\text { latest } \\
\text { technical and }\end{array}$ & $\begin{array}{l}\text { a. Encouraging the } \\
\text { submission of } \\
\text { scientific research to } \\
\text { keep abreast of the } \\
\text { latest updates in } \\
\text { health service } \\
\text { provision } \\
\text { B. Encouraging them } \\
\text { to put forward ideas }\end{array}$ & & \\
\hline
\end{tabular}




\section{International Journal of Business Management and Economic Review}

Vol. 4, No. 03; 2021

ISSN: $2581-4664$

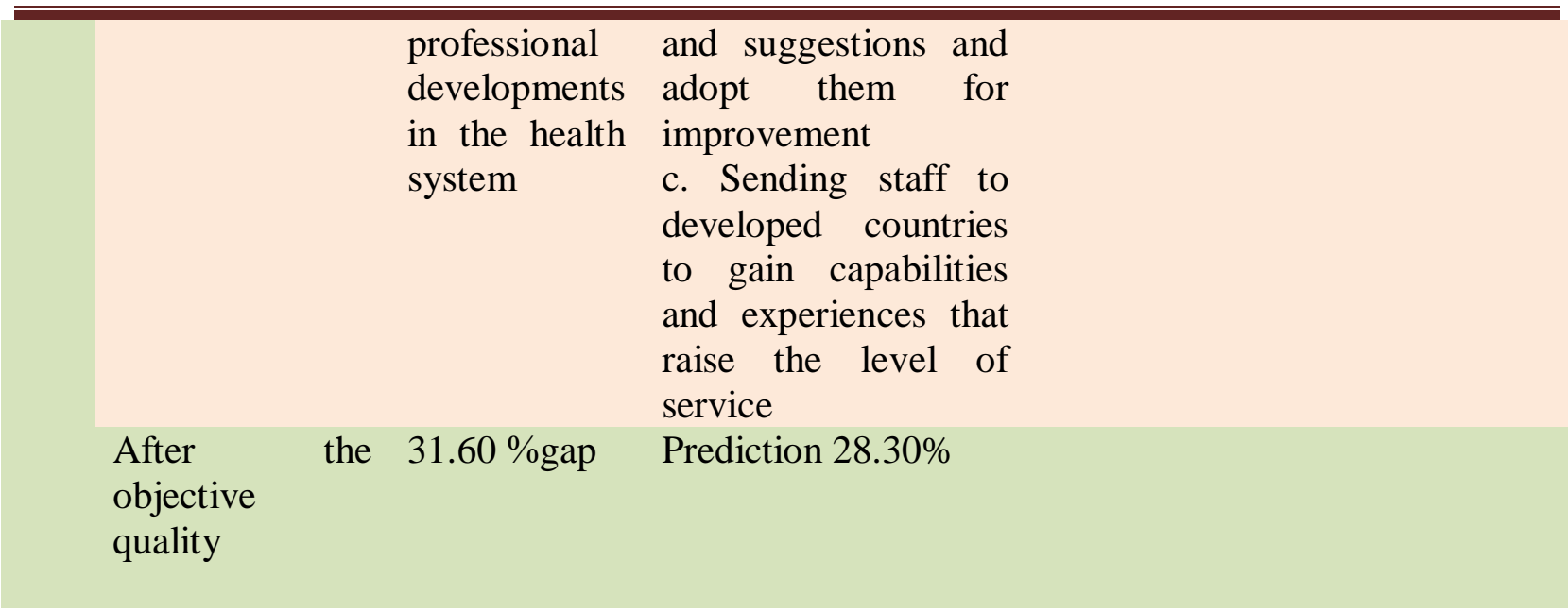

The second stage: Implementation (DO): In this stage, the improvement plan is implemented as in Table (3), the improvement plan is implemented for the objective quality dimension.

\section{Table (3) Implementation of the improvement plan for the objective quality dimension}

Executing the plan as expected (were there surprises or challenges deviations from the plan)

Working with the electronic system will facilitate work for doctors and other health service providers through which to follow up the patients' condition and all related results (examinations, radiological reports, etc.) to avoid errors in diagnosis or treatment, as well as conducting training courses to improve efficiency and raise awareness to reflect the standards Results The impact on the patient or the health system shows the end result of our improvement work.
1. There will be difficulty when implementing in the first days of changing the behavior of the medical staff and the behavior of patients in documenting and protecting the patient information in the electronic medical file

2. It takes time to learn a new system

3. The need to redesign the workflow to accommodate the new system.

4. Increasing the test scale after the initial tests, ie improper use.

5. The concern of the employees that the workflow of the new changes made to the system may weaken the quality and safety of the system.

The third stage: Study: In this stage, the data and results that were identified in the previous stage (DO) are analyzed, compared to the identified goals (taking into account that all changes that have occurred should contribute to improving the quality of the specified processes), and the figure ( 2) The fishbone diagram shows the objective quality dimension. 


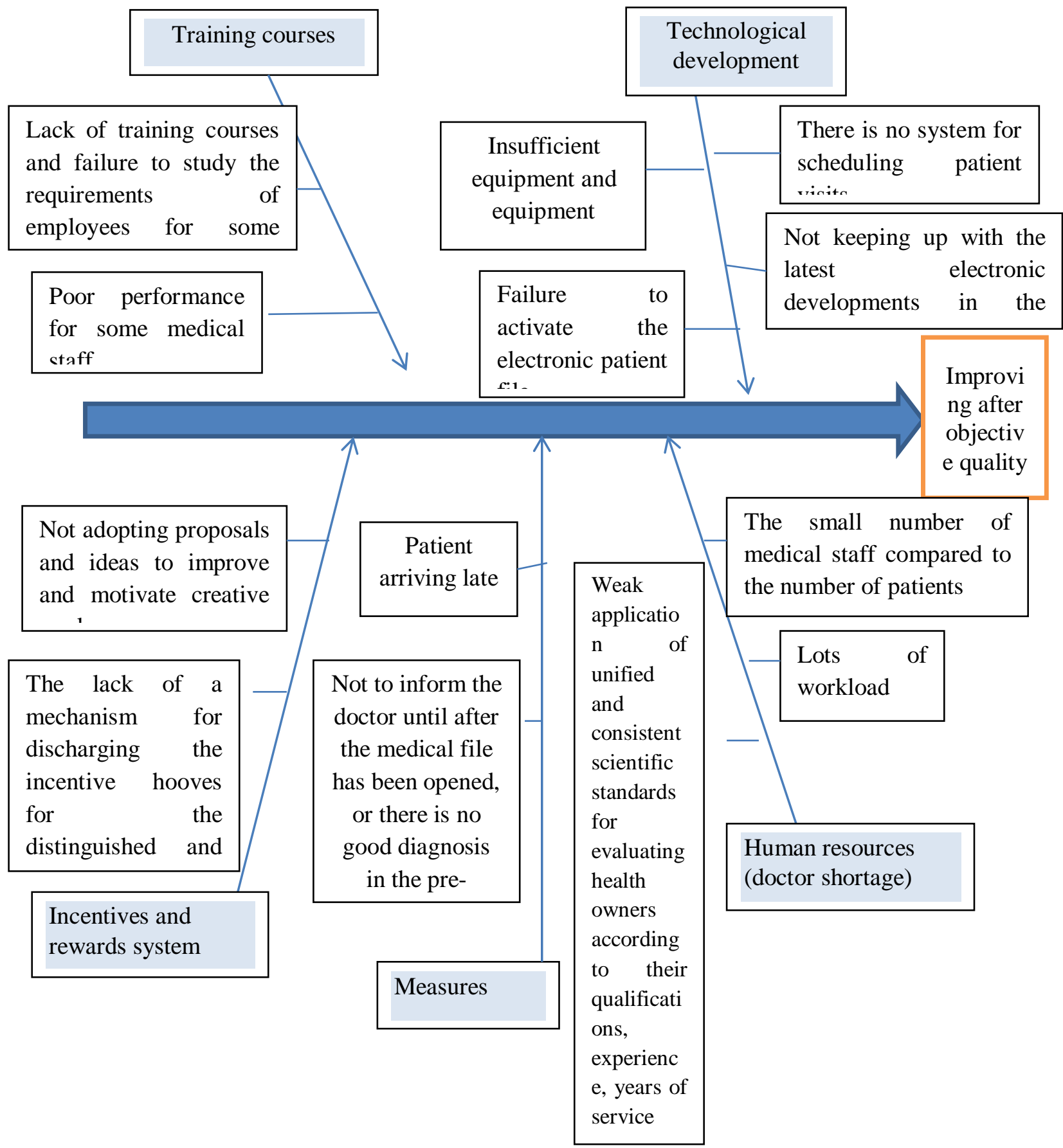

Figure (2) Fishbone diagram for the objective quality dimension

Phase IV: Action (ACT): The final step in the PDSA rapid improvement cycle is the Act phase based on what has been learned from the test results such as implementing solutions and 
International Journal of Business Management and Economic Review

Vol. 4, No. 03; 2021

ISSN: $2581-4664$

adopting changes if successful. One of the following stages is approved and worked:

A. Adapt: modify changes and conduct another PDSA cycle. What will we change in the next test?

B. Approval: Extending changes in the organization to the rest of the medical city departments, personnel, etc. How will the test be expanded in the next cycle?

D. Abandonment: This idea of change is not being implemented. Methods and methods are reviewed and a new cycle begins.

2- After the quality of the process:

Weaknesses and strengths will be improved for the process quality dimension according to the following Deming technique stages:

The first stage: Planning(plan): In this stage, a plan is developed to improve the weaknesses and strengthen the strengths, and an improvement plan is made for the quality dimension of the process as in Table (4).

Table (4) Improvement plan for the practical quality dimension

\begin{tabular}{|c|c|c|c|c|c|}
\hline No. & Weak points & $\begin{array}{l}\text { optimization } \\
\text { process }\end{array}$ & Working procedures & $\begin{array}{l}\text { Entity } \\
\text { responsible for } \\
\text { implementation }\end{array}$ & $\begin{array}{l}\text { Completion } \\
\text { time }\end{array}$ \\
\hline 1 & $\begin{array}{lr}\text { Long } & \text { patient } \\
\text { waiting } & \text { to } \\
\text { receive } & \text { medical } \\
\text { services. } & \end{array}$ & $\begin{array}{l}\text { Reducing } \\
\text { patient waiting } \\
\text { time to receive } \\
\text { medical } \\
\text { services. }\end{array}$ & $\begin{array}{l}\text { a. Increasing the } \\
\text { number of medical } \\
\text { personnel }\end{array}$ & $\begin{array}{l}\text { Higher } \\
\text { Management }\end{array}$ & $\begin{array}{l}4 \text { to } \\
\text { months }\end{array}$ \\
\hline 2 & $\begin{array}{l}\text { The hospital is } \\
\text { distinguished by } \\
\text { providing the } \\
\text { medical services } \\
\text { that it promised } \\
\text { to provide to the } \\
\text { patient }\end{array}$ & $\begin{array}{l}\text { Fulfilling the } \\
\text { promises that } \\
\text { the service } \\
\text { meets the } \\
\text { patient's needs, } \\
\text { according to } \\
\text { what is } \\
\text { announced to } \\
\text { achieve the } \\
\text { hospital's goals }\end{array}$ & $\begin{array}{l}\text { Providing a safe and } \\
\text { healthy environment } \\
\text { suitable for the } \\
\text { needs and } \\
\text { expectations of the } \\
\text { patient }\end{array}$ & $\begin{array}{l}\text { Higher } \\
\text { management } \\
\text { and workers in } \\
\text { the Medical } \\
\text { City }\end{array}$ & \\
\hline & \multicolumn{5}{|l|}{ strength point } \\
\hline & $\begin{array}{l}\text { The medical } \\
\text { staff is } \\
\text { distinguished by } \\
\text { providing } \\
\text { medical services } \\
\text { in accordance } \\
\text { with professional } \\
\text { standards }\end{array}$ & $\begin{array}{l}\text { Adhering to } \\
\text { the } \\
\text { profession's } \\
\text { regulations } \\
\text { and } \\
\text { activating it }\end{array}$ & $\begin{array}{l}\text { Working with the } \\
\text { principles of medical } \\
\text { ethics and } \\
\text { professional } \\
\text { behavior for all } \\
\text { medical professions } \\
\text { under the motto of } \\
\text { the patient first. }\end{array}$ & $\begin{array}{l}\text { Higher } \\
\text { management }\end{array}$ & \\
\hline
\end{tabular}




\section{International Journal of Business Management and Economic Review}

Vol. 4, No. 03; 2021

ISSN: 2581-4664

\section{After the quality $33.40 \% \quad 30.20 \%$}

of the operation

The second stage: Implementation (DO): In this stage, the improvement plan will be implemented, and the workflow will be in this stage as in Table (5), the implementation of the improvement plan for the quality dimension of the process.

Table (5) Implementation of the improvement plan for the process quality dimension Executing the plan as expected (were there surprises or challenges deviations from the plan)

Working to change the behavior of staff and patients by responding quickly to the residing patient and meeting his needs as soon as possible. The medical service is provided according to the schedule at the time specified for the patient in the electronic system and communication with patients regarding appointments, that is, an appointment system should be used to schedule patients' reviews, and handle the order of patients who visit without a prior appointment Patients accept appointments if there is justification for that. And arranging cases according to importance, to determine the priority of providing health services in emergency cases, to avoid favoritism and external interventions, and when the number of medical staff increases compared to the number of patients and the service provider is not late for working hours, especially during the peak period in the morning, since some patients need to undergo examinations while they are in a state. Fasting, will lead to no delay in the health service and consequently the patient's satisfaction with the quality of the service provided.
1. There will be difficulty when implementing in the first days of changing the behavior of the medical staff and the behavior of patients in documenting and protecting the patient information in the electronic medical file

2. .It takes time to learn a new system

3. The need to redesign the workflow to accommodate the new system.

4. .Increasing the test scale after the initial tests, ie improper use.

5. The concern of the employees that the workflow of the new changes made to the system may weaken the quality and safety of the system.

The third stage: Study: In this stage, the factors that hinder the implementation process are studied and analyzed, as shown in Figure (4), a fishbone diagram for the quality of infrastructure. 


\section{International Journal of Business Management and Economic Review}

Vol. 4, No. 03; 2021

ISSN: 2581-4664

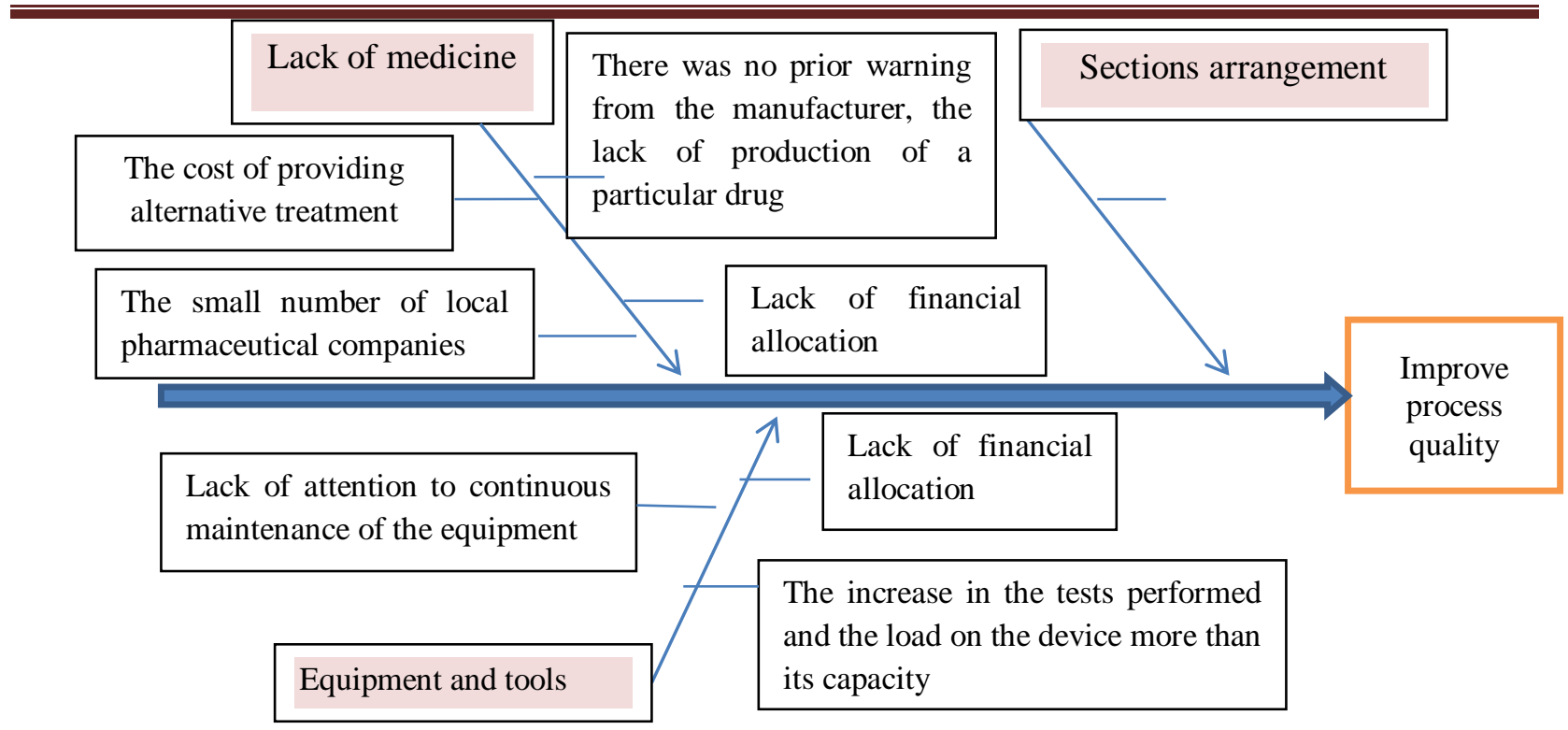

Figure (3) Fishbone diagram for the quality of infrastructure

Phase IV: Action (ACT): The final step in the PDSA Rapid Improvement cycle is the Action Phase (Act) based on what has been learned from the exam. Accreditation and work is done on one of the following stages:

A. Adapt: modify changes and conduct another PDSA cycle. What will we change in the next test?

B- Approval: Extending changes in the organization to the rest of the medical city departments, personnel, etc. How will the test be expanded in the next cycle?

C. Abandonment: This idea of change is not being implemented. Methods and methods are reviewed and a new cycle begins.

\section{4.- .After the interactive quality}

The weaknesses and strengths of the interactive quality dimension will be improved according to the following Deming Technology phases:

The first stage: Planning (plan): In this stage, a plan is developed to improve the weaknesses and strengthen the strengths of the interactive quality dimension as in Table (8) the improvement plan for the interactive quality dimension.

Table (8) Improvement plan for the interactive quality dimension

\begin{tabular}{|c|c|c|c|c|c|c|}
\hline No. & Weak points & $\begin{array}{l}\text { optimization } \\
\text { process }\end{array}$ & $\begin{array}{l}\text { Working } \\
\text { procedures }\end{array}$ & & $\begin{array}{l}\text { Entity } \\
\text { responsible for } \\
\text { implementation }\end{array}$ & $\begin{array}{l}\text { Completion } \\
\text { time }\end{array}$ \\
\hline 1 & $\begin{array}{l}\text { The hospital's } \\
\text { lack of interest in } \\
\text { the patient's }\end{array}$ & $\begin{array}{l}\text { Attention to the } \\
\text { patient's } \\
\text { financial and }\end{array}$ & $\begin{array}{l}\text { a. Providing } \\
\text { service to } \\
\text { patient in }\end{array}$ & $\begin{array}{l}\text { the } \\
\text { the } \\
\text { an }\end{array}$ & $\begin{array}{l}\text { Higher } \\
\text { Management } \\
\text { Medical staff }\end{array}$ & $\begin{array}{l}8 \text { to } \\
10 \text { tonths }\end{array}$ \\
\hline
\end{tabular}


International Journal of Business Management and Economic Review

Vol. 4, No. 03; 2021

ISSN: 2581-4664

\begin{tabular}{|c|c|c|c|}
\hline $\begin{array}{l}\text { financial and } \\
\text { social situation }\end{array}$ & social status & $\begin{array}{l}\text { equitable manner, } \\
\text { not on the basis of } \\
\text { discrimination } \\
\text { based on race, } \\
\text { religion, customs, } \\
\text { or source of } \\
\text { income. } \\
\text { employing personal } \\
\text { relationships, all } \\
\text { patients will receive } \\
\text { equal medical } \\
\text { treatment } \\
\text { B. Exempting some } \\
\text { patients who are } \\
\text { unable to pay fees } \\
\text { in return for } \\
\text { conducting some } \\
\text { tests, in } \\
\begin{array}{lr}\text { appreciation of } \\
\text { their financial } \\
\text { situation. }\end{array}\end{array}$ & \\
\hline $\begin{array}{l}\text { Lack of interest } \\
\text { in taking into } \\
\text { account the } \\
\text { psychological } \\
\text { state of the } \\
\text { patient and } \\
\text { dealing with him } \\
\text { sympathetically }\end{array}$ & $\begin{array}{l}\text { Attention to the } \\
\text { moral culture } \\
\text { of how to deal } \\
\text { with the } \\
\text { patient, taking } \\
\text { into account the } \\
\text { psychological } \\
\text { state he is } \\
\text { going through } \\
\text { because of his } \\
\text { illness }\end{array}$ & $\begin{array}{l}\text { Preparing training } \\
\text { programs to } \\
\text { develop behaviors } \\
\text { of interacting with } \\
\text { patients and } \\
\text { supporting them, } \\
\text { assessing their } \\
\text { conditions, caring, } \\
\text { caring and } \\
\text { embracing and } \\
\text { avoiding expressing } \\
\text { blame, it will } \\
\text { increase the degree } \\
\text { of his recovery as it } \\
\text { is closely related to } \\
\text { the psychological } \\
\text { state of the patient }\end{array}$ & Medical staff \\
\hline $\begin{array}{l}\text { After } \\
\text { interactive } \\
\text { quality }\end{array}$ & Gap $40.80 \%$ & Prediction $37.40 \%$ & \\
\hline
\end{tabular}

The second stage: Implementation (DO): In this stage, the improvement plan will be 


\section{International Journal of Business Management and Economic Review}

Vol. 4, No. 03; 2021

ISSN: 2581-4664

implemented, and the workflow in this stage will be as in Table (9) the implementation of the improvement plan for the interactive quality dimension.

Table (9): Implementation of the improvement plan for the interactive quality dimension Executing the plan as expected (were there surprises or challenges deviations from the plan)

Collecting data and information about the patient's psychological, social, and physical condition and pathology to know how to deal with the patient, each according to his condition, and the patient's knowledge of his rights and how to deal with them, and conducting training courses to educate the patient's rights and medical ethics owed to the medical staff and how to deal with the patient with kindness, care, respect, appreciation of their feelings and protecting their dignity, Appreciating the psychological state he is going through, in addition to the hospital's interest in the patient's financial situation, not giving appointments to patients on the private ward, and disbursing some medications or tests from outside the hospital, which increases the patient's burden.
1. It will appear difficult when implementing in the early days in changing the behavior of the medical staff and the behavior of patients in documenting and all protecting patient information in the electronic medical file

2. It takes time to learn a new system

3. The workflow needs to be redesigned to accommodate the new system.

4. Increasing the test scale after the initial tests, ie improper use

The third stage: Study: In this stage, the factors that hinder the implementation process are studied and analyzed, as in Figure () the fishbone diagram for the interactive quality dimension.

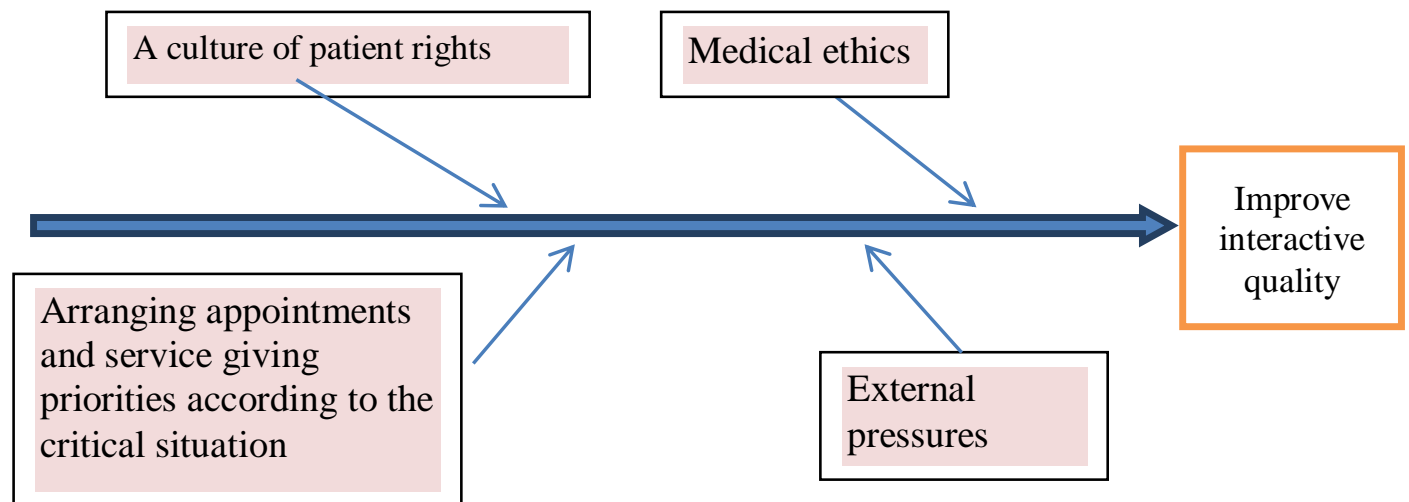

Figure (5) Fishbone diagram for the interactive quality dimension

Phase IV: Action (ACT): The final step in the PDSA Rapid Improvement cycle is the Action Phase (Act) based on what has been learned from the exam. Accreditation and work is done on one of the following stages: 
International Journal of Business Management and Economic Review

Vol. 4, No. 03; 2021

ISSN: 2581-4664
A. Adapt: modify changes and conduct another PDSA cycle. What will we change in the next test?
B. Approval: Extending changes in the organization to the rest of the medical city departments, personnel, etc. How will the test be expanded in the next cycle?
D. Abandonment: This idea of change is not being implemented. Methods and methods are reviewed and a new cycle begins.

\section{5-.After the quality of the overall feeling}

Weaknesses and strengths will be improved for the quality dimension of the process according to the following Deming technique stages:

The first stage: planning(plan): In this stage, a plan is developed to improve the weaknesses and strengthen the strengths according to Table (10) of the improvement plan for the dimension of quality of the general feeling.

Table (10) improvement plan for the dimension of quality of the general feeling

\begin{tabular}{|c|c|c|c|c|c|}
\hline No. & Weak points & $\begin{array}{l}\text { optimization } \\
\text { process }\end{array}$ & Working procedures & $\begin{array}{l}\text { Entity } \\
\text { responsible for } \\
\text { implementation }\end{array}$ & $\begin{array}{l}\text { Completion } \\
\text { time }\end{array}$ \\
\hline 1 & $\begin{array}{l}\text { Weakness in } \\
\text { infection } \\
\text { prevention } \\
\text { programs and } \\
\text { preventive } \\
\text { measures } \\
\text { against } \\
\text { infectious } \\
\text { diseases }\end{array}$ & $\begin{array}{l}\text { Improving and } \\
\text { developing the } \\
\text { program and } \\
\text { preventive } \\
\text { measures taken } \\
\text { against } \\
\text { infectious } \\
\text { diseases }\end{array}$ & $\begin{array}{l}\text { a. Develop an } \\
\text { effective program to } \\
\text { prevent and control } \\
\text { infection with all the } \\
\text { tools and materials } \\
\text { necessary for the } \\
\text { success of the } \\
\text { program } \\
\text { B. Work periodically } \\
\text { to evaluate the } \\
\text { infection prevention } \\
\text { and control program } \\
\text { and evaluate it in } \\
\text { terms of the } \\
\text { measures taken and } \\
\text { measures to provide } \\
\text { a safe environment } \\
\text { for the patient. }\end{array}$ & $\begin{array}{l}\text { Infection } \\
\text { Control and } \\
\text { Prevention } \\
\text { Committee }\end{array}$ & $\begin{array}{l}10 \text { to } \\
12 \text { months }\end{array}$ \\
\hline 2 & $\begin{array}{l}\text { The patient's } \\
\text { lack of } \\
\text { confidence that } \\
\text { he is dealing } \\
\text { with a qualified } \\
\text { and competent } \\
\text { medical staff }\end{array}$ & $\begin{array}{l}\text { Increasing the } \\
\text { patient's } \\
\text { confidence and } \\
\text { making him } \\
\text { feel safe that he } \\
\text { is dealing with } \\
\text { a qualified and }\end{array}$ & $\begin{array}{l}\text { The interaction of } \\
\text { the medical staff } \\
\text { with the patient is a } \\
\text { basic rule that should } \\
\text { be formed to instill a } \\
\text { spirit of reassurance } \\
\text { when performing the }\end{array}$ & & \\
\hline
\end{tabular}


International Journal of Business Management and Economic Review

Vol. 4, No. 03; 2021

ISSN: 2581-4664

\begin{tabular}{|c|c|c|}
\hline $\begin{array}{l}\text { while receiving } \\
\text { health services }\end{array}$ & $\begin{array}{l}\text { efficient } \\
\text { medical staff }\end{array}$ & $\begin{array}{l}\text { service, such as } \\
\text { providing sufficient } \\
\text { information about } \\
\text { examination, } \\
\text { diagnosis and } \\
\text { treatment, i.e. the } \\
\text { ability of the medical } \\
\text { staff to treat them in } \\
\text { the way they } \\
\text { expected }\end{array}$ \\
\hline \multicolumn{3}{|l|}{ strength point } \\
\hline $\begin{array}{l}\text { The medical } \\
\text { staff in the } \\
\text { hospital takes } \\
\text { into account the } \\
\text { customs, } \\
\text { traditions and } \\
\text { social norms of } \\
\text { patients }\end{array}$ & $\begin{array}{l}\text { Respecting } \\
\text { the rights of } \\
\text { the patient in } \\
\text { terms of } \\
\text { customs and } \\
\text { traditions. }\end{array}$ & $\begin{array}{l}\text { Strengthening and } \\
\text { informing the } \\
\text { medical staff of their } \\
\text { role by respecting the } \\
\text { patient's culture and } \\
\text { habits during } \\
\text { examination or } \\
\text { treatment }\end{array}$ \\
\hline $\begin{array}{l}\text { After the quality } \\
\text { of the general } \\
\text { feeling }\end{array}$ & Gap $32.40 \%$ & Prediction $29.20 \%$ \\
\hline
\end{tabular}

The second stage: Implementation (DO): In this stage, the improvement plan is implemented, and the workflow in this stage will be as in Table (11) the improvement plan for the quality dimension of the general feeling.

Table (11) Improvement plan for the dimension of quality of the general feeling

Executing the plan as expected (were there surprises or challenges deviations from the plan)

Develop and improve the infection prevention program by providing all resources such as disinfectants, sterilizers and tools that help us to control or protect from acquired diseases such as appropriate use of personal protective equipment, best practices for cleaning hands, comprehensive implementation of maskwearing policies and appropriate training on infection prevention, control and awareness, and work on Evaluate the program periodically to see how effective it is in decreasing

1. There will be difficulty when implementing in the first days of changing the behavior of the medical staff and the behavior of patients in documenting and protecting the patient's information in the electronic medical file.

2. It takes time to learn a new system.

3. The workflow needs to be redesigned to accommodate the new system.

4. Increasing the test scale after the initial 


\section{International Journal of Business Management and Economic Review}

Vol. 4, No. 03; 2021

ISSN: 2581-4664

acquired infections.

tests, ie improper use.

The third stage: Study: In this stage, the factors that hinder the implementation process are studied and analyzed, as in Figure (6) the fishbone diagram for the quality of the general feeling.

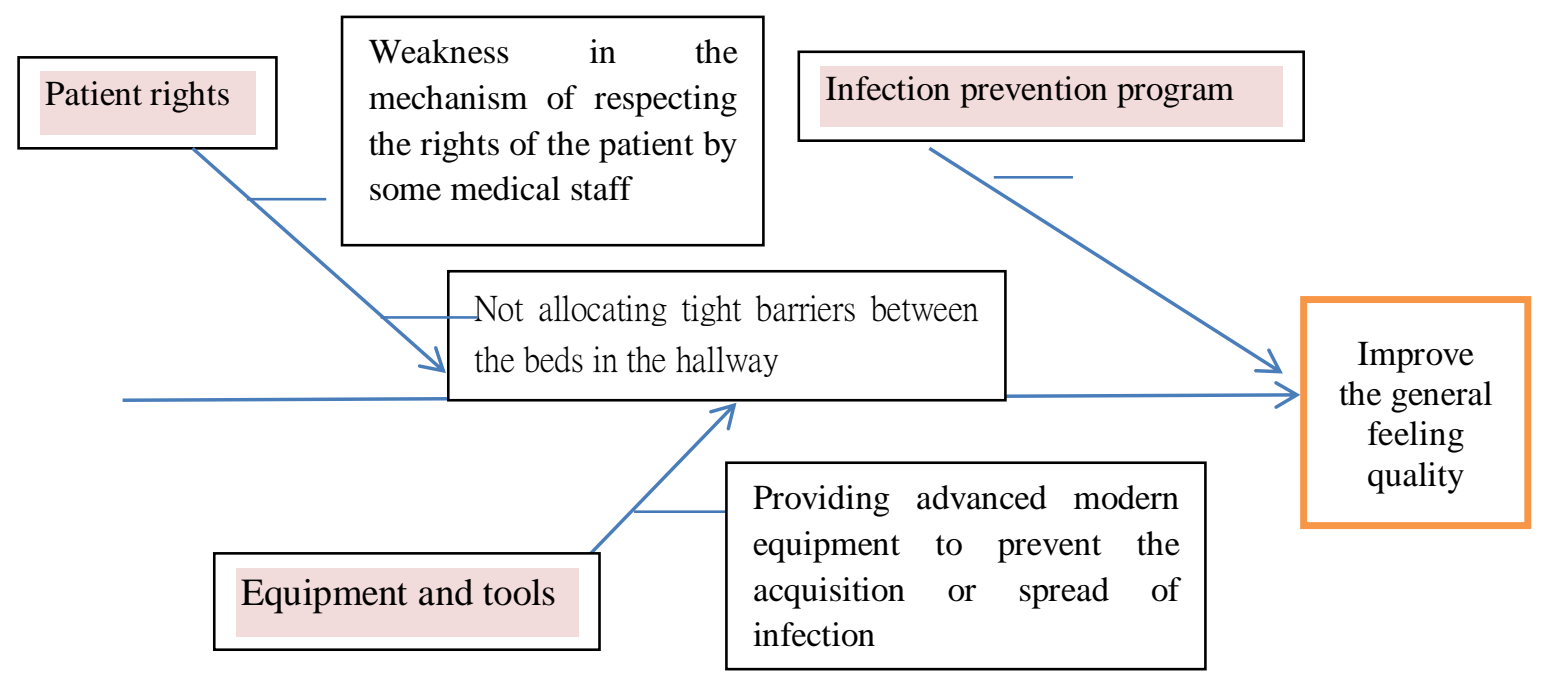

Figure (6) Fishbone diagram for the overall feeling quality dimension.

Phase IV: Action (ACT): The final step in the PDSA Rapid Improvement cycle is the Action Phase (Act) based on what has been learned from the exam. Reliance and work are carried out on one of the following stages:

A. Adapt: modify changes and conduct another PDSA cycle. What will we change in the next test?

B. Approval: Extending changes in the organization to the rest of the medical city departments, personnel, etc. How will the test be expanded in the next cycle?

C. Abandonment: This idea of change is not being implemented. Methods and methods are reviewed and a new cycle begins.

\section{Second: Test and discuss the research hypothesis}

The extent to which PDSA can improve the quality of health service and obtain patient satisfaction will be clarified graphically if it turns out that PDSA is very useful to reach the goals using the limited resources that we have, which were clarified in the improvement plan and incorporate new ideas into routine practice about By involving health service providers in the depth of the problem and solving problems themselves. But motivating patients was the most challenging part because they are overburdened and have negative expectations of the health service. This was attempted to be overcome through regular communication with patients, problem solving skills and good coordination which finally helped us achieve the goals. And figure (7) the graph of the success of the five cycles of PDSA technology in improving the health service. 


\section{International Journal of Business Management and Economic Review}

Vol. 4, No. 03; 2021

ISSN: 2581-4664

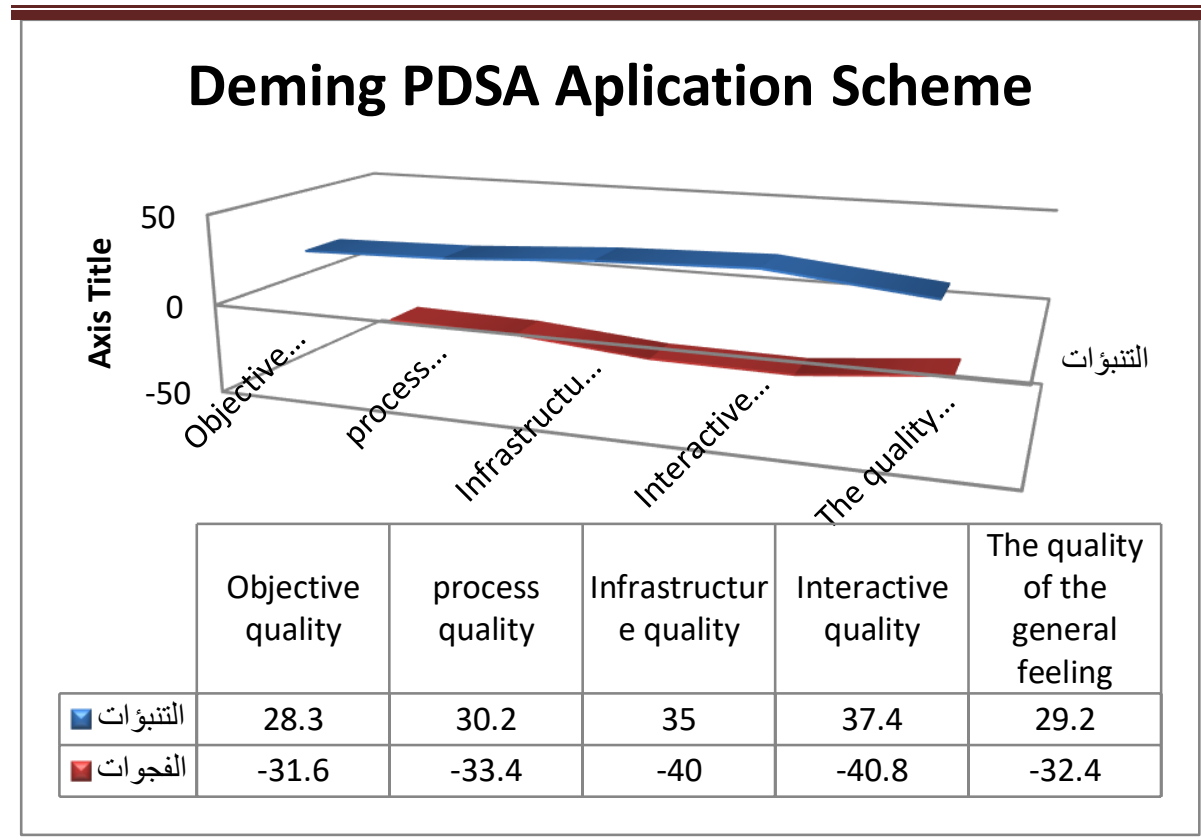

As it was noted for the objective quality dimension, our gap was $(-31.60 \%)$ when implementing the improvement plan, which would reduce the gap by (28.30\%), and also for the process quality dimension, our gap was $(-33.40 \%)$ when working with PDSA technology). From reducing the gap, which amounts to $(30.20 \%)$, and then to the dimension of the quality of the infrastructure, our gap ratio was (40-40\%), and when applying the technology we were able to bridge the gap by $35 \%$ ), and as for the quality of interaction, the gap in this dimension was (40.80). -) And when applying the technique, we were able to bridge the gap by $37.40 \%$ (-) and finally for the dimension of grandmother of general feeling, the gap was $(-32.40 \%)$ and the success rate was $(29.20 \%)$.

The improvements that were obtained in the accuracy of the success of applying the methodology that we relied on the basic principles of its application in terms of starting to implement the change on a small size and setting a prediction for success, and then the technology was used repeatedly to reach success at the end of the change and all procedures were documented to benefit from them in the Deming technique suffix. Thus, through the results, this supports the second hypothesis that states (the possibility of using the modified Deming technique (PDSA) to improve the weaknesses and enhance the strengths in the quality of health services in the medical city study sample), as the modified Deming technique was able to improve the weaknesses and enhance the strengths in the quality of services health.

\section{CONCLUSIONS AND RECOMMENDATIONS} First: the conclusions

The most important conclusions will be presented based on the stages of the modified Deming technique, as follows:

1. Planning phase (PLAN)

A- Lack of interest in developing strategic and operational plans that can be modified according to the variables of the surrounding environment of the medical city. 


\section{International Journal of Business Management and Economic Review}

Vol. 4, No. 03; 2021

ISSN: 2581-4664

B. Lack of interest in giving an opportunity to all employees to present ideas and solutions to improve the change plan for the weaknesses of the Medical City and to develop the work of an electronic system.

2. .Implementation Phase (DO)

a. Failure to employ modern technological techniques in implementing the activities and procedures of the improvement plan for strengths and weaknesses in order to increase the efficiency of the health service.

B. Difficulty in changing the culture of workers and patients in the first days of implementing the improvement plan for the medical city.

3. study stage

a. Weakness of the medical city's interest in discussing and studying the problems that impede the implementation of the improvement plan for weaknesses

B. Weakness in analyzing the data collected in the implementation phase of the dimensional improvement plan (5Qs) model by adopting quality improvement tools, including the cause and effect tool to diagnose the main and subsidiary causes of the implementation phase.

4. Action Phase (ACT)

a. The medical city's lack of interest in adopting modern systems to facilitate and facilitate work procedures and activities with the aim of continuous improvement.

B. Utilize the data of the initial and post PDSA cycles so that the team knows what will change in the process of subsequent PDSA cycles.

\section{RECOMMENDATIONS}

Recommendations will be written based on the conclusions and as follows:

1. The plan stage

a. Attention to developing strategic and operational plans according to the circumstances surrounding the medical city, because it is the first and most important step to raise the level of quality of health services.

B. Empowering and encouraging workers and giving them opportunities to participate in developing an improvement plan for weaknesses because they are in direct contact with work and face the problems facing patients.

2. Implementation Phase (DO)

Introducing modern technological means to obtain accuracy in completing the service easily and not disturbing the patient with routine procedures.

3. study stage

a. It is necessary to pay attention to the analysis of the data collected during the implementation phase to discuss its conformity with the goal set in the plan phase.

B. Adopting quality improvement tools in data analysis and problem diagnosis, i.e. accuracy in collecting facts and investigating matters such as the cause and effect tool to know the causes of the root problem that may hinder the process of implementing the service quality improvement plan .

4. Action Phase (ACT)

Modern and advanced systems should be adopted to facilitate the procedures for the work of the improvement results that were reached during the three stages of the modified Deming technology (PDSA) either by adapting to the new change to improve the quality of service with 


\section{International Journal of Business Management and Economic Review}

Vol. 4, No. 03; 2021

ISSN: 2581-4664

appropriate modifications to be ready for adoption, or adopting this change without making any modifications and expanding the procedures Other courses include all Medical City lobbies.

\section{REFERENCES}

1.Papcun ,George Joseph,(2019), MEDICAL DEVICE QUALITY: MANAGING CYBERSECURITY DESIGN REQUIREMENTS THROUGH THE APPLICATION OF PDSA AND QFD", Master of Science in Quality Assurance ,California State University Dominguez Hills

2.McNicholas, Chris McNicholas, Laura Lennox, Thomas Woodcock, Derek Bell, Julie E Reed,(2019)," Evolving quality improvement support strategies to improve Plan-Do-Study-Act cycle fidelity: aretrospective mixed-methods study" BMJ QualSaf: first, BMJ QualSaf, p 356365.

3.McNicholas, Christopher Martin,(2016)," A scientific approach to improvement: the use of Plan-Do-Study-Act cycles in healthcare" degree of Doctor of Philosophy, Imperial College London.

4.Knudsen, SørenValgreen, Henrik Vitus Bering Laursen, SørenPaaskeJohnsen, Paul Daniel Bartels, Lars Holger Ehlers and Jan 12.Mainz,(2019),"Can quality improvement improve the quality of care? A systematic review of reported effects and methodological rigor in plan-dostudy-act projects", BMC Health Services Research (2019) 19:683 https://doi.org/10.1186/s12913-019-4482-6.

5.Taylor ,Michael J, Chris McNicholas, Chris Nicolay, AraDarzi, Derek Bell, Julie E Reed ,(2014) "Systematic review of the application of the plan-do-study-act method to improve quality in healthcare" BMJ QualSaf, 290-298. doi:10.1136/bmjqs-2013-001862.

6.Speroff, T. \& O'Connor, G.T., 2004. Study designs for PDSA quality improvement research. Quality management in health care, 13(1), pp.17-32.

8.Leis, J. A., \&Shojania, K. G.(2016). A primer on PDSA: Execut-ing plan-do-study-act cycles inpractice, not just in name. BMJ Quality \&Safety,bmjqs, 572-577. Doi.Org/10.1136/bmjqs2016-00614.

9.Marrs, Michael,(2019)," USING THE PLAN-DO-STUDY-ACT (PDSA) CYCLE TO INCREASE PRODUCT FIRMWARE ADOPTION RATE", Master of Science in Quality Assurance, California State University Dominguez Hills

10. Al-Ramadin, Areig Y.,(2018), EMPLOYING THE PDSA CYCLE TO IMPROVE THE QUALITY OF BLENDED LEARNING IN BASIC MEDICAL SCIENCE COURSES, Master of Science, California State University Dominguez Hills.

11. Saier , Martin Christopher , (2017)," Going back to the roots of W.A. Shewart (and further) $\&$ introduction of a new CPD Cycle ", International Journal of Managing Projects in Business, Vol. 10 Iss 1.

12.L. Norman, Clifford,(2016), Evolution of PDSA and the Difference Between PDSA and PDCA.

13.Alexander, J., Warren, D. L., Williams, S., \&McClaskey, D. (2018). Using an Early-Course Improvement Process to Enhance Business Education: The Case for a Simple PDSA-Cycle Improvement Approach. Available at SSRN 3198238.

14.Peter Donnelly \& Paul Kirk (2015) "Use the PDSA model for effective change management", Education for Primary Care (2015) 279-81, DOI:10.1080/14739879.2015.11494356. 
International Journal of Business Management and Economic Review

Vol. 4, No. 03; 2021

ISSN: 2581-4664

15.Coury Jennifer, Jennifer L. Schneider, Jennifer S. Rivelli, Amanda F. Petrik, Evelyn Seibel, BrieshonD'Agostini,Stephen H. Taplin, Beverly B. Green and Gloria D. Coronado, (2017), "Applying the Plan-Do-Study-Act (PDSA) approach to a large pragmatic study involving safety net clinics", BMC Health Services Research 1:10 